\title{
Improved RNA Extraction from Woody Plants for the Detection of Viral Pathogens by Reverse Transcription-Polymerase Chain Reaction
}

\author{
Donald J. MacKenzie, Morven A. McLean, Srima Mukerji, and Margaret Green, Centre for Plant Health, Ag- \\ riculture and Agri-Food Canada, 8801 East Saanich Road, Sidney, BC Canada V8L 1H3
}

\begin{abstract}
MacKenzie, D. J., McLean, M. A., Mukerji, S., and Green, M. 1997. Improved RNA extraction from woody plants for the detection of viral pathogens by reverse transcription-polymerase chain reaction. Plant Dis. 81:222-226.

An efficient procedure for the extraction of high-quality RNA from woody plants without the use of phenol, organic solvents, or alcohol precipitation is described. The method employs commercially available spin-column matrices and mitigates the inhibitory effects of plant polysaccharides and polyphenolic compounds commonly observed on subsequent polymerase chain reaction amplification when conventional extraction methods are applied to woody plant species. The method described has been successfully used in the development of highly sensitive reverse transcription-polymerase chain reaction (RT-PCR) techniques for the detection of a number of viruses in their woody hosts. The viruses detected included apple stem grooving capillovirus (ASGV), apple stem pitting virus, Prunus necrotic ringspot ilarvirus (PNRSV), grapevine fanleaf and Arabis mosaic nepoviruses, and grapevine leafroll-associated closterovirus type 3. The method described was equally effective for the extraction of viral RNA from either budwood, leaves, or flower blossoms as determined by the equivalent RT-PCR detection of ASGV and PNRSV from these tissues. Detection of viral RNA in samples of total plant RNA prepared using this method was found to be as sensitive as was previously described for the immunocapture RT-PCR technique.
\end{abstract}

The polymerase chain reaction (PCR) has, in recent years, seen numerous applications for the in vitro detection and diagnosis of disease pathogens, and its impact in the field of plant pathology has been the subject of a recent review (7). The advantages of the PCR technique include high specificity, the theoretical sensitivity to detect a single target molecule in a complex mixture, and high sample throughput. In comparison with serological reagents, PCR primers with any desired degree of selectivity can be synthesized, at a much lower comparable cost than that associated with the development of monoclonal or polyclonal antibodies. These facts, coupled with the vast increase in nucleotide sequence data available for plant pathogens of viral, bacterial, or fungal origin, have enhanced the attractiveness of the PCR technique as a viable diagnostic tool. Specifically, for many plant viral pathogens with RNA genomes, the technique of reverse transcription (RT)-PCR proved much

Corresponding author: D. J. MacKenzie

E-mail: mackenzied@em.agr.ca

Accepted for publication 29 October 1996.

Publication no. D-1996-1216-07S

(C) 1997 Department of Agriculture and Agri-

Food, Government of Canada more effective than comparable enzymelinked immunosorbent assay (ELISA) techniques, especially in situations where the virus is present in low titer or where good quality antisera are not available.

The chief limiting factor in the application of the PCR technique in routine diagnosis lies in the preparation of good quality nucleic acid, free of PCR inhibitors. This is especially true in the case of woody plants such as grapevine (14) and many tree fruit varieties of Malus, Prunus, and Pyrus origin (11). Most standard nucleic acid extraction procedures do not remove contaminating plant polysaccharides or polyphenolic compounds, which can have direct inhibitory effects on subsequent PCR amplification (4,7[DM1]). Attempts to overcome these limitations included the development of more elaborate extraction methods, which employ polyvinylpyrrolidone (PVP) or cation-exchange resins to chelate polyphenolics. The use of specialized polymeric matrices, which irreversibly adsorb inhibitor compounds, together with polyethylene glycol (PEG) precipitation as an alternate to ethanol precipitation of nucleic acids, has been described for the RT-PCR detection of prune dwarf ilarvirus (PDV) in stone fruit (17). A modified RT-PCR technique in which viral RNA is prepared directly from antibody-captured virus particles (immuno- capture RT-PCR) has also been described as a method for mitigating the effects of PCR inhibitors $(3,13,20)$.

In this paper, we describe the application, with minor modification, of a commercially available RNA extraction kit (RNeasy, Qiagen, Inc., Chatsworth, CA) in the development of RT-PCR diagnostic methods for the detection of a number of plant viruses in woody hosts. The method has been used successfully with host plants from the genera Malus, Prunus, Pyrus, and Vitis to detect a diverse range of viruses, including apple stem grooving capillovirus (ASGV), apple stem pitting virus (ASPV), Prunus necrotic ringspot ilarvirus (PNRSV), Arabis mosaic (ArMV) and grapevine fanleaf (GFLV) nepoviruses, and grapevine leafroll-associated closterovirus type 3 (GLRaV-3).

ASGV, together with apple chlorotic leaf spot virus (ACLSV) and ASPV, occur worldwide, causing serious disease in both apple and pear. ASGV causes stem grooving and graft union abnormalities in apple and, together with ACLSV, has been implicated in apple topworking disease in Japan (21). PNRSV, in its many strains, infects all Prunus species and, alone or together with prune dwarf virus, causes severe losses worldwide on susceptible varieties of all its hosts (16). PNRSV is spread on infected pollen by foraging honeybees (15) and by infected seeds. GFLV and ArMV are two important nematode-transmitted pathogens of grapevine, with the former being responsible for fanleaf degeneration, the oldest known virus disease of Vitis (8). GLRaV-3 is a phloem-limited, nonmechanically transmissible closterovirus that, together with grapevine leafroll-associated virus 1 , has been most often associated with grapevine leafroll disease (2).

While the use of RT-PCR for the detection of ArMV (9), GFLV (18), and GLRaV-3 (13) has been previously reported, this is the first report on the application of this technique for the detection of ASGV, ASPV, and PNRSV.

\section{MATERIALS AND METHODS}

Plant material. All viral isolates were obtained from naturally infected woody hosts (Vitis, Malus, Prunus, and Pyrus) maintained at the Centre for Plant Health. In the case of ASGV, ASPV, and PNRSV, 
additional isolates were obtained courtesy of G. Mink, Washington State University, National Research and Support Project 5, Prosser, WA, and indirectly from Suzanne Hurtt, USDA-ARS, Beltsville, MD. Samples consisted of either budwood, collected at various times during the year, or leaf or blossom tissue collected during the spring or summer months.

Oligonucleotide primer sequences. DNA amplification primers (Table 1) were selected by computer analysis (Primer Select, DNAStar, Inc., Madison, WI) of the published nucleotide sequences of the coat protein coding regions of ASGV (19), ASPV (10), PNRSV (5), ArMV (1), and GFLV (3). For GLRaV-3, a primer pair was chosen that amplified a portion of the p20 open reading frame (6). All primers were selected so that the amplification products following RT-PCR were between 300 and $550 \mathrm{bp}$ in length and between 42.2 and $51.3 \% \mathrm{G}+\mathrm{C}$ content. Individual primer $\mathrm{Tm}$ values varied between $53^{\circ} \mathrm{C}$ and $62^{\circ} \mathrm{C}(\Delta \mathrm{G}$ from $-39.2 \mathrm{kcal} / \mathrm{mol}$ to -48.7 $\mathrm{kcal} / \mathrm{mol}$ ), and primer pair Tm values were matched within $1^{\circ} \mathrm{C}$. Primers were synthesized by Genosys Biotechnologies, Inc., The Woodlands, TX 77380-3600.

RNA extraction. The following method was used to prepare viral RNA from either budwood, leaf, or blossom tissue obtained from infected plants.

In the case of budwood, $20-\mathrm{cm}$ lengths of dormant wood were thoroughly washed and "shaved" using a mechanical pencil sharpener (APSCO standard sharpener; the epidermal tissue was not removed from the wood prior to preparation). The sharpener was washed with running tap water and dried with forced air between samples. If not used immediately, wood shavings were stored at $-80^{\circ} \mathrm{C}$.

Approximately 0.5 to $0.6 \mathrm{~g}$ of bark shavings, leaf tissue, or blossom tissue was placed in a sample bag (Agdia, Elkhart, IN) suitable for use on a Homex grinder (Bioreba, South Bend, IN) and homogenized with $5 \mathrm{ml}$ of lysis buffer composed of $4 \mathrm{M}$ guanidine isothiocyanate, $0.2 \mathrm{M}$ sodium acetate, pH 5.0, $25 \mathrm{mM}$ EDTA, $2.5 \%$ (wt/vol) PVP-40, and 1\% (vol/vol) 2mercaptoethanol (added just before use). The homogenate $(1 \mathrm{ml})$ was transferred to a graduated microcentrifuge tube (using a disposable plastic transfer pipette), mixed with $100 \mu \mathrm{l}$ of $20 \%$ (wt/vol) sarkosyl, and incubated at $70^{\circ} \mathrm{C}$ with agitation $(1,200$ $\mathrm{rpm}$ ) for $10 \mathrm{~min}$ using an Eppendorf thermomixer. Approximately 600 to $650 \mu \mathrm{l}$ of homogenate was transferred to a QIAShredder (Qiagen) column (using a new disposable plastic transfer pipette) and centrifuged at $14,000 \times g$ for $2 \mathrm{~min}$ in an Eppendorf microcentrifuge. Then, $250 \mu \mathrm{l}$ of the column flowthrough was transferred to a new 1.5-ml microcentrifuge tube, mixed with $225 \mu \mathrm{l}$ of $95 \%$ ethanol, loaded onto an RNeasy (Qiagen) column, and centrifuged at $8000 \times g$ for $45 \mathrm{~s}$. The flowthrough was discarded, and $700 \mu \mathrm{l}$ of RW1 buffer (Qiagen) was applied to the column and washed through by centrifugation at $8,000 \times g$ for $15 \mathrm{~s}$. The column was transferred to a clean 2-ml collection tube, and $500 \mu \mathrm{l}$ of RPE buffer (Qiagen) was applied to the column and washed through by centrifugation at $8,000 \times g$ for $15 \mathrm{~s}$. The flowthrough was discarded, and an additional $0.5 \mathrm{ml}$ of RPE buffer was applied to the column, followed by centrifugation at $14,000 \times g$ for $5 \mathrm{~min}$ to ensure removal of all of the alcohol. The column was then transferred to a new $1.5-\mathrm{ml}$ microcentrifuge tube and RNA eluted by application of $100 \mu \mathrm{l}$ of RNase-free water, followed by centrifugation at $8,000 \times g$ for $1 \mathrm{~min}$. The collection tubes were appropriately labeled, and RNA was stored at $-80^{\circ} \mathrm{C}$ until used for RT-PCR analysis.

Viral cDNA synthesis and PCR amplification. First-strand cDNA synthesis was performed using recombinant Moloney murine leukemia virus (MMLV) reverse transcriptase (Superscript II; Gibco/BRL, Burlington, Ont.) and total RNA prepared from either bark scrapings, leaf tissue, or blossom tissue. In a 0.20 -ml thin-walled PCR tube, $5 \mu \mathrm{l}$ of RNA extract was mixed with an equal volume of RT master mix, composed of $100 \mathrm{mM}$ Tris- $\mathrm{HCl}, \mathrm{pH} 8.3$, $80 \mathrm{mM} \mathrm{KCl}, 12 \mathrm{mM} \mathrm{MgCl} 2,0.20 \mathrm{mg}$ of BSA per $\mathrm{ml}, 20 \mathrm{mM}$ dithiothreitol, $1 \mathrm{mM}$ deoxynucleoside triphosphates (dNTPs), $1 \mu \mathrm{M}$ appropriate complementary primer (see Table 1), and either $2 \mathrm{U} / \mu \mathrm{l}$ (ASGV, ASPV), $10 \mathrm{U} / \mu \mathrm{l}$ (PNRSV, GFLV, GLRaV-3), or $14 \mathrm{U} / \mu \mathrm{l}$ (ArMV) of Superscript-II RT, and incubated for 45 $\min$ at $42^{\circ} \mathrm{C}$.

Following RT, $40 \mu \mathrm{l}$ of PCR master mix $(25 \mathrm{mM}$ Tris- $\mathrm{HCl}, \mathrm{pH} 8.4,62.5 \mathrm{mM} \mathrm{KCl}$, $2.5 \%$ [wt/vol] sucrose, $0.125 \mathrm{mM}$ cresol red, $0.25 \mathrm{mM}$ dNTPs, $0.625 \mathrm{mM} \mathrm{MgCl}_{2}$, $0.625 \mu \mathrm{M}$ complementary DNA primer, $0.625 \mu \mathrm{M}$ homologous DNA primer, and

Table 1. DNA primers for reverse transcription-polymerase chain reaction (RT-PCR) amplification

\begin{tabular}{|c|c|c|c|c|}
\hline Virus & Primer & $\begin{array}{l}\text { Length } \\
\text { (bases) }\end{array}$ & Sequence & $\begin{array}{c}\text { Amplified } \\
\text { DNA size (bp) }\end{array}$ \\
\hline \multirow{2}{*}{$\overline{A S G V}$} & C6396 & 22 & 5'-CTGCAAGACCGCGACCAAGTTT-3' & 524 \\
\hline & H5873 & 25 & 5'-CCCGCTGTTGGATTTGATACACCTC-3' & \\
\hline \multirow{2}{*}{ ASPV } & C8849 & 23 & 5'-TGCCTCAAAGTACACCCCTCAGT-3' & 316 \\
\hline & H8534 & 19 & 5'-CGCCAAGAAATGCCACAGC-3' & \\
\hline \multirow[t]{2}{*}{ PNRSV } & C537 & 25 & 5'-ACGCGCAAAAGTGTCGAAATCTAAA- $3^{\prime}$ & 455 \\
\hline & $\mathrm{H} 83$ & 25 & 5'-TGGTCCCACTCAGAGCTCAACAAAG-3' & \\
\hline \multirow[t]{2}{*}{ GFLV } & $\mathrm{C} 3310$ & 24 & 5'-GATGGTAACGCTCCCGCTGCTCTT-3' & 312 \\
\hline & H2999 & 25 & 5'-TCGGGTGAGACTGCGCAACTTCCTA-3' & \\
\hline \multirow[t]{2}{*}{ ArMV } & C1642 & 24 & 5'-TTGGCCCAGATATAGCGTAAAAAT-3' & 519 \\
\hline & H1124 & 19 & 5'-CAGCGGATTGGGAGTTCGT-3' & \\
\hline \multirow{2}{*}{ GLRaV-3 } & C629 & 21 & 5'-CGGCACGATCGTACTTTCTAA-3' & \\
\hline & H330 & 21 & 5'-GATGCTTTCGCGTATTTCTTG-3' & 300 \\
\hline
\end{tabular}

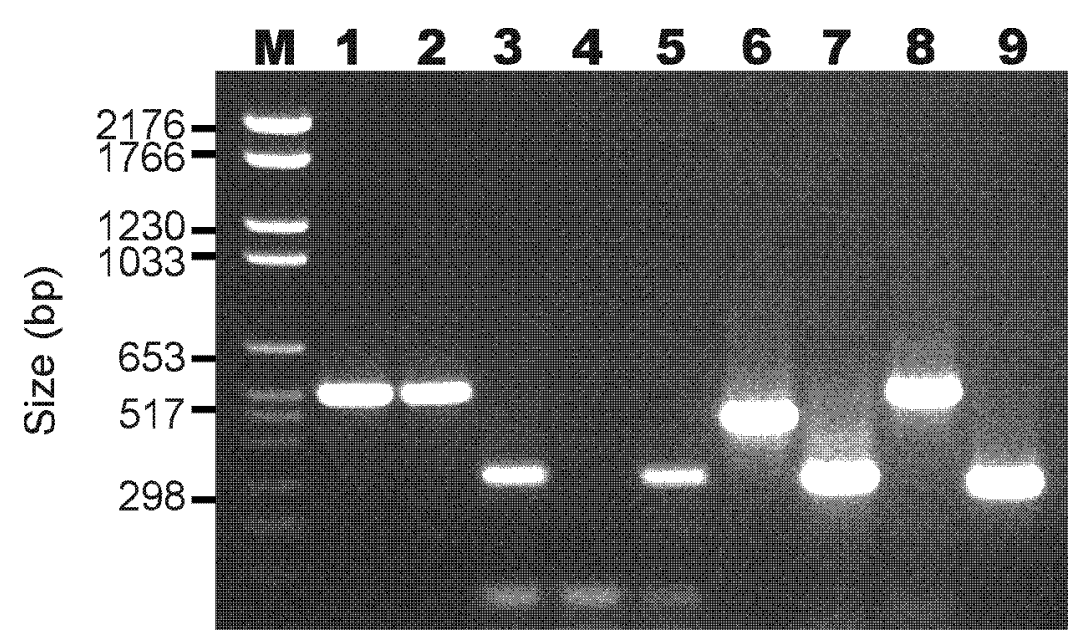

Fig. 1. Total RNA extracts prepared from budwood obtained from infected apple (lanes 1, 4, 5), pear (lanes 2,3), cherry (lane 6), and grapevine (lanes 7, 8,9) were tested by reverse transcription-polymerase chain reaction (RT-PCR) for apple stem grooving virus (ASGV; lanes 1,2), apple stem pitting virus (ASPV; lanes 3, 4, 5), Prunus necrotic ringspot virus (PNRSV; lane 6), grapevine fanleaf virus (GFLV; lane 7), Arabis mosaic virus (ArMV; lane 8), and grapevine leafroll-associated virus type 3 (GLRaV-3; lane 9). The RNA extract tested in lanes 2 and 3 was from a pear plant with a mixed infection of ASGV and ASPV, and the extract tested in lanes 1 and 4 was from an apple variety that was only infected with ASGV. Following RT-PCR, the amplification mixtures were fractionated by agarose gel electrophoresis, and DNA products were visualized by UV transillumination after staining with ethidium bromide. The sizes of amplified DNA fragments were determined relative to molecular weight markers (lane M). 


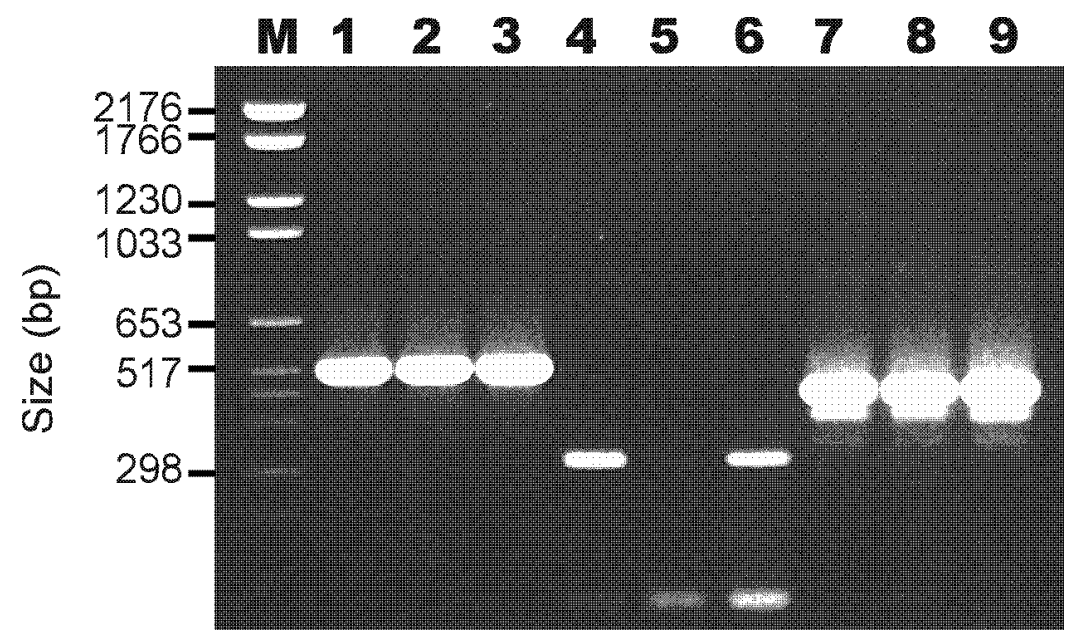

Fig. 2. Reverse transcription-polymerase chain reaction (RT-PCR) detection of apple stem grooving virus (ASGV; lanes 1 to 3), apple stem pitting virus (ASPV; lanes 4 to 6), or Prunus necrotic ringspot virus (PNRSV; lanes 7 to 9) in total RNA extracts prepared from either budwood (lanes 1, 4, 7), leaf tissue (lanes 2, 5, 8), or flower blossoms (lanes 3, 6, 9) from either apple (lanes 1 to 6) or cherry (lanes 7 to 9). Amplified products were detected by UV transillumination of ethidium bromidestained agarose gels following electrophoresis. DNA size markers are shown in lane M.

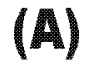

(B)

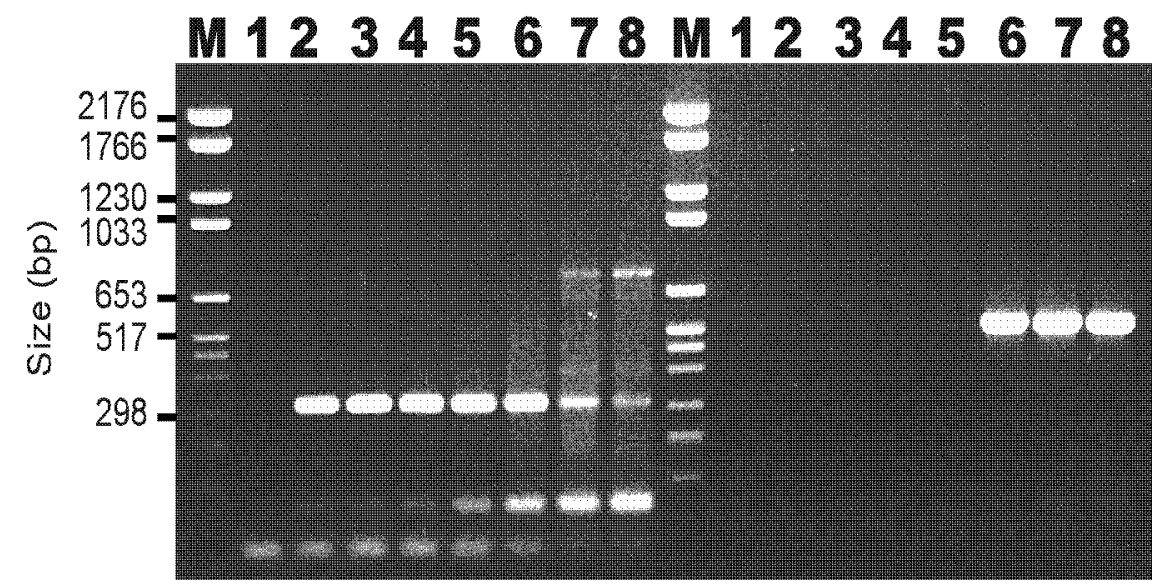

Fig. 3. Effect of Moloney murine leukemia virus (MMLV) reverse transcriptase concentration on the amplification of (A) apple stem pitting virus or (B) Arabis mosaic virus specific sequences by reverse transcription-polymerase chain reaction (RT-PCR). Reverse transcription (RT) was performed using 5 $\mu \mathrm{l}$ of RNA extract from infected budwood and either 0 (lane 1), 2 (lane 2), 5 (lane 3), 10 (lane 4), 25 (lane 5), 50 (lane 6), 75 (lane 7), or 100 (lane 8) units of Superscript II RT in a total volume of $10 \mu 1$. DNA size markers are shown in lane $\mathrm{M}$.

$0.0625 \mathrm{U} / \mu \mathrm{l}$ recombinant Taq DNA polymerase [Gibco/BRL]) was added to each reaction mixture, mixed, and overlaid with $25 \mu \mathrm{l}$ of light mineral oil (Sigma-Aldrich Canada, Mississauga, Ont.). Sucrose and cresol red were added to the PCR reaction mixtures as a density modifying agent and a tracking dye, respectively, in order to facilitate the direct loading of mixtures onto agarose gels following amplification. PCR was performed for 35 cycles of $94^{\circ} \mathrm{C}$ for $30 \mathrm{~s}$ (denaturation), 50 to $60^{\circ} \mathrm{C}$ for $45 \mathrm{~s}$ (annealing) (ArMV, GLRaV-3: $50^{\circ} \mathrm{C}$; GFLV: $52^{\circ} \mathrm{C}$; ASPV, PNRSV: $54^{\circ} \mathrm{C}$; ASGV: $60^{\circ} \mathrm{C}$ ), and $72^{\circ} \mathrm{C}$ for $60 \mathrm{~s}$ (elongation) using a Stratagene Robocycler Gradient 9600 thermocycler. Samples were incubated for $5 \mathrm{~min}$ at $72^{\circ} \mathrm{C}$ following completion of the last cycle and then stored at $4^{\circ} \mathrm{C}$ until analyzed by electrophoresis.

Analysis of PCR amplified products. Aliquots $(18 \mu \mathrm{l})$ of PCR-amplified DNA were analyzed by electrophoresis through $1.8 \%$ agarose gels for $1.5 \mathrm{~h}$ in $1 \times$ TPE buffer (90 mM Tris-phosphate, $\mathrm{pH} 8.2,2$ $\mathrm{mM}$ EDTA) at $75 \mathrm{~V}$. Separated fragments were visualized using a UV transilluminator following staining with ethidium bromide $(1 \mu \mathrm{g} / \mathrm{ml})$. The size of amplified DNA products was determined using DNA Molecular Weight Markers VI (0.15 to $2.1 \mathrm{kbp}$; Boehringer Mannheim, Laval).

\section{RESULTS AND DISCUSSION}

The RNA extraction protocol described in this paper has facilitated the routine detection of a number of different plant viral pathogens in their woody hosts using RT-PCR. The method was based on the commercially available RNeasy kit and was superior to other methods, in that it mitigated the effects of phenolic compounds and other inhibitory substances, avoided the use of organic solvents and phenol, and was extremely rapid. A modification of the manufacturer's tissue lysis buffer, which included the addition of PVP ( $2.5 \%$ [wt/vol] final concentration) and $\mathrm{pH}$ buffering to 5.0 with $0.2 \mathrm{M}$ sodium acetate, was instrumental in improving the reproducibility of RNA extractions from diverse host species.

High-quality RNA suitable for use in RT-PCR could be obtained from apple, pear, peach, or grapevine budwood, allowing for the detection of ASGV, ASPV, PNRSV, ArMV, GFLV, and GLRaV-3 (Fig. 1). The ability to use budwood as a reliable source of viral RNA allowed the routine detection of these viruses in infected plants throughout the year rather than restricting it to the spring or summer months, when leaf or flower blossom tissue was readily available. In comparative extractions performed with budwood, leaves, or flower blossoms, it was found, in the case of ASGV and PNRSV, that these tissues were equivalent sources of viral RNA (Fig. 2). In ASPV, however, apple leaf tissue proved to be a much poorer source, and the virus was often not detected, or only weakly detected, in this tissue (Fig. 2, lane 5) compared with either apple budwood (Fig. 2, lane 4) or apple flower blossoms (Fig. 2, lane 6). This same phenomenon was observed for ASPV-infected pear (results not shown) and may be due to a lower virus titer in leaf tissue compared with other plant tissues.

During the course of optimizing the RTPCR protocols for each virus, it was noted that the RT (Superscript II) concentration used during the reverse transcription reaction had a profound effect on the quantity of specifically amplified DNA that was produced, and that this effect was different depending on the virus in question. For ArMV, GFLV, GLRaV-3, and PNRSV, it was observed that at least 25 to 50 Units of RT were required to produce detectable levels of amplified DNA following PCR, and that additional RT had very little effect. This is illustrated for ArMV in Figure 3B (lanes 1 to 8 ). Contrary results were obtained for both ASGV and ASPV. For each of these viruses, detectable quantities of specifically amplified DNA were produced following RT-PCR with as little as 2 Units of RT per reaction mixture (ASPV; Fig. 3A, lane 2), and RT concentrations greater than 50 Units per reaction mixture resulted in lower yields of specifically amplified material (ASPV; Fig. 3A, lanes 7 


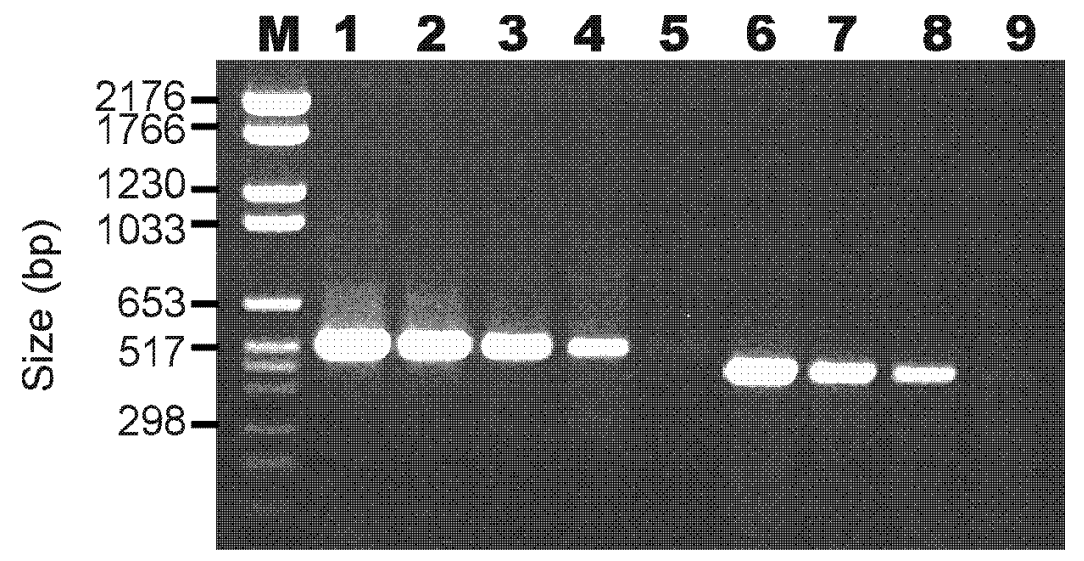

Fig. 4. Sensitivity of the reverse transcription-polymerase chain reaction (RT-PCR) technique in detecting apple stem grooving virus (ASGV; lanes 1 to 5) or Prunus necrotic ringspot virus (PNRSV; lanes 6 to 9) in infected samples of apple or cherry budwood. Budwood tissue homogenate from ASGV-infected apple (lane 1) or PNRSV-infected cherry (lane 6) was diluted 1:10 (lanes 2, 7), 1:100 (lanes 3,8), 1:1,000 (lanes 4, 9) or 1:10,000 (lane 5) with homogenate from healthy apple or cherry, respectively. Total RNA was then extracted using the method described and tested for the presence of each of these viruses by RT-PCR. DNA size markers are shown in lane M.

to 8). While the exact cause of this phenomenon is not known, it does underscore the importance of empirically verifying the optimal RT concentration when developing a new assay protocol.

The sensitivity of the RT-PCR technique was determined for ASGV and PNRSV on samples of total RNA prepared from serial dilutions of virus-infected plant tissue homogenate. Bark scrapings from a virusinfected sample of budwood were homogenized as described in Materials and Methods, and serial 10-fold dilutions of this homogenate were prepared in corresponding tissue homogenate from uninfected plant tissue. Total RNA extracts were then prepared from each diluted sample, and 5- $\mu$ l aliquots were tested by RTPCR as previously described. Readily detectable amplification products were observed at either $1: 100$ or $1: 1,000$ dilutions of the initial infected tissue homogenate for PNRSV (Fig. 4, lane 8) or ASGV (Fig. 4 , lane 4), respectively. This latter dilution represented the equivalent of $0.56 \mu \mathrm{g}$ of ASGV-infected bark scrapings.

The immunocapture RT-PCR (IC/RTPCR) was previously reported to be much more sensitive than regular RT-PCR, with the successful amplification of reverse transcribed plum pox virus RNA from a 1:10,000 dilution of infected plant extract, corresponding to $1.5 \mu \mathrm{g}$ of infected tissue (20). Considering the likely variability in virus titer in infected tissue, the combination of improved RNA extraction protocol and the RT-PCR technique described in this report have a level of sensitivity comparable to that described for IC/RT-PCR. As previously indicated by Wetzel et al. (20), IC/RT-PCR and regular RT-PCR have the same inherent level of sensitivity, but the principal advantage of the former technique is that it obviates the deleterious effects of various PCR-inhibitor compounds that often contaminate RNA extractions prepared by conventional methods.

For many viruses like ASGV and ASPV, which are causes of significant disease in Malus and Pyrus species, the most commonly used methods of diagnosis still rely on biological indexing using either woody or herbaceous indicator plants (12). While serological reagents are available for these viruses, the use of ELISA for routine screening has been limited to their detection in herbaceous indicator plants, or to specific times of the year from young leaf tissue or flower blossoms obtained from their woody hosts. It is anticipated that the methods described in this paper will facilitate the development of rapid and sensitive diagnostic techniques that can be used year-round for the specific detection of these and other important viral pathogens directly in their woody hosts.

\section{ACKNOWLEDGMENTS}

We thank the staff of the Centre for Plant Health (Sidney, BC) for assistance, and we thank G. Mink and B. Howell (Washington State University, IR-2/NRSP-5, Prosser, WA) and S. Hurtt (USDA-ARS, Beltsville, MD) for providing samples of virus-infected plant material and virus isolates.

\section{LITERATURE CITED}

1. Bertioli, D. J., Harris, R. D., Edwards, M. L., Cooper, J. I., and Hawes, W. S. 1991. Transgenic plants and insect cells expressing the coat protein of Arabis mosaic virus produce empty virus-like particles. J. Gen. Virol. 72:1801-1809.

2. Bovey, R., and Martelli, G. P. 1992. Directory of Major Virus and Virus-like Diseases of Grapevines. Mediterranean Fruit Improvement Council \& International Council for the Study of Viruses and Virus Diseases of the Grapevine, Bari, Italy.

3. Brandt, S., Ibl, M., and Himmler, G. 1995. Coat protein gene sequence of an Austrian isolate of grapevine fanleaf virus. Arch. Virol. 140:157-164.

4. Demeke, T., and Adams, R. P. 1992. The effects of plant polysaccharides and buffer additives on PCR. Biotechniques 12:332334.

5. Guo, D., Maiss, E., Adam, G., and Capser, R. 1995. Prunus necrotic ringspot ilarvirus: $\mathrm{Nu}$ cleotide sequence of the RNA 3 and the relationship to other ilarviruses based on coat protein comparison. J. Gen. Virol. 76:10731079.

6. Habili, N., Fazeli, C. F., Ewart, A., Hamilton, R., Cirami, R., Saldarelli, P., Minafra, A., and Rezaian, M. A. 1995. Natural spread and molecular analysis of grapevine leafroll-associated virus 3 in Australia. Phytopathology 85:1418-1422.

7. Henson, J. M., and French, R. 1993. The polymerase chain reaction and plant disease diagnosis. Annu. Rev. Plant Pathol. 31:81109.

8. Hewitt, W. B., Martelli, G., Dias, H. F., and Taylor, R. H. 1970. Grapevine fanleaf virus. Description of Plant Viruses No. 28. Commonw. Mycol. Inst./Assoc. Appl. Biol., Kew, Surrey, England.

9. Ipach, U., Altmayer, B., and Eichhorn, K. W. 1992. Detection of Arabis mosaic virus using the polymerase chain reaction (PCR). Vitis 31:213-219.

10. Jelkmann, W. 1994. Nucleotide sequences of apple stem pitting virus and of the coat protein gene of a similar virus from pear associated with vein yellows disease and their relationship with potex- and carlaviruses. J. Gen. Virol. 75:1535.

11. Korschineck, I., Himmler, G., Sagl, R., Steinkellner, H., and Katinger, H. W. D. 1991. A PCR membrane spot assay for the detection of plum pox virus RNA in bark of infected trees. J. Virol. Methods 31:139-146.

12. Leone, G., Lindner, J. L. 1995. Back-transmission of a virus associated with apple stem pitting and pear vein yellows, from Nicotiana occidentalis to apple and pear indicators. Acta Hortic. 386:72-77.

13. Minafra, A., and Hadidi, A. 1994. Sensitive detection of grapevine virus A, B, or leafrollassociated III from viruliferous mealybugs and infected tissue by cDNA amplification. J. Virol. Methods 47:175-188

14. Minafra, A., Hadidi, A., and Martelli, G. P. 1992. Detection of grapevine closterovirus A in infected grapevine tissue by reverse transcription-polymerase chain reaction. Vitis 31:221-227.

15. Mink, G. I. 1983. The possible role of honeybees in long distance spread of prunus necrotic ringspot virus from California into Washington sweet cherry orchards. Page 85 in: Plant Virus Disease Epidemiology. R. T. Plumb and J. M. Thresh, eds. Blackwell Scientific, Oxford

16. Nyland, G., Gilmer, R. M., and Moore, J. D. 1976. "Prunus" ring spot group. Page 179 in: Virus Diseases and Noninfectious Disorders of Stone Fruits in North America. U.S. Dep. Agric., Agric. Handb. No. 437.

17. Parakh, D. R., Shamloul, A. M., Hadidi, A., Scott, S. W., Waterworth, H. E., Howell, H E., and Mink, G. I. 1995. Detection of prune dwarf ilarvirus from infected stone fruits using reverse transcription-polymerase chain reaction. Acta Hortic. 386:421-430.

18. Rowhani, A., Chay, C., Golino, D. A., and Falk, B. W. 1993. Development of a polymerase chain reaction technique for the detection of grapevine fanleaf virus in grapevine tissue. Phytopathology 83:749753.

19. Serghini, M. A., Fuchs, M., Pinck, M., Reinbolt, J., Walter, B., and Pinck, L. 1990. RNA2 of grapevine fanleaf virus: Sequence analysis and coat protein cistron location. J. Gen. Virol. 71:1433-1441. 
20. Wetzel, T., Candresse, T., Macquaire, G., Ravelonandro, M., and Dunez, J. 1992. A highly sensitive immunocapture polymerase chain reaction method for plum pox potyvirus detection. J. Virol. Methods 39:27-37.
21. Yanase, H., Yamaguchi, A., Mink, G. I., and Sawamura, K. 1979. Back transmission of apple chlorotic leafspot virus (type strain) to apple and production of apple topworking disease symptoms in Maruba Kaido (Malus prunifolia Borkh. var. ringo
Asami). Ann. Phytopathol. Soc. Jpn. 45:369-374

22. Yoshikawa, N., Sasaki, E., Kato, M., and Takahashi, T. 1992. The nucleotide sequence of apple stem grooving capillovirus genome. Virology 191:98-105. 